FOLIA POMERANAE UNIVERSITATIS TECHNOLOGIAE STETINENSIS

Folia Pomer. Univ. Technol. Stetin., Oeconomica 2017, 335(87)2, 7-18

Michał BIERNACKI

\title{
OCENA ZAPISÓW NA SEMINARIA I WYBORU PROMOTORA PRZEZ STUDENTÓW RACHUNKOWOŚCI NA STUDIACH I STOPNIA
}

\section{ASSESSMENT OF REGISTRATION FOR SEMINARS AND SELECTION OF SUPERVISOR BY THE STUDENT OF ACCOUNTING COURSE AT THE BACHELOR STUDIES}

Katedra Rachunkowości Finansowej i Kontroli, Uniwersytet Ekonomiczny we Wrocławiu ul. Komandorska 118/120, 53-345 Wrocław, e-mail: michal.biernacki@ue.wroc.pl

\begin{abstract}
Summary. This article is written to analyze the form of subscriptions for seminars to assess the system of records, a form of contact with the supervisor and specify the weaknesses of the current model used by students of accounting at the University of Economics in Wroclaw. Students of Generation Z are people wild open to the world, but waiting an individual approach to them. They expect to contact with them in an individual way. The article presents the results of a survey conducted among third year students of full-time studies degree at the Faculty of Management, Information Technology and Finance of Wroclaw University of Economics. The results confirm the thesis of the need to modify the approach to the seminars by the promoters and the university.
\end{abstract}

Słowa kluczowe: I stopień, seminarium, praca licencjacka.

Key words: bachelor studies, accounting, seminar.

\section{WSTĘP}

Studenci zaliczani do tzw. pokolenia $Z$ są obecnie dominującą grupą na polskich uczelniach wyższych. Są to osoby urodzone po roku 1990, bardzo dobrze znające najnowsze rozwiązania techniczno-technologiczne i potrafiące z nich korzystać, a równocześnie zagubione w realnym świecie i mające problemy w kontaktach międzyludzkich "na żywo" (Pawłowska, http://natemat.pl/55617,generacja-z-mlodzi-otwarci-wychowani-w-dobrobycie-zyjacy-w-swiecie-wirtualnym-skazani-na-kryzys).

Przedstawiciele tej generacji, jako studenci uczelni wyższych, zobligowani są do przystąpienia do egzaminu dyplomowego, aby sfinalizować edukację na poziomie co najmniej licencjackim (lub równorzędnym).

Zgodnie z art. 167a Ustawy o szkolnictwie wyższym warunkiem przystąpienia do egzaminu dyplomowego jest pozytywna ocena pracy dyplomowej, która ma być samodzielnym opracowaniem określonego zagadnienia naukowego lub artystycznego, lub dokonaniem artystycznym. Ma ona prezentować ogólną wiedzę i umiejętności studenta związane z danym kierunkiem studiów, poziomem i profilem kształcenia oraz potwierdzać umiejętności samodzielnego analizowania i wnioskowania. Pracę dyplomową może stanowić w szczególności praca pisemna, opublikowany artykuł, praca projektowa etc. (Ustawa z dnia 27 lipca 2005 r. Prawo o szkolnictwie wyższym). 
Zagadnienia związane z przygotowaniem pracy dyplomowej oraz egzaminem dyplomowym na Uniwersytecie Ekonomicznym we Wrocławiu reguluje Uchwała Senatu uczelni z dnia 28 kwietnia 2016 r. W paragrafie 22 jest mowa o pracach dyplomowych, których napisanie jest obligatoryjne zarówno dla studentów studiów I, jak i II stopnia, co wynika z programów studiów. Szczegółowe wymagania określone są przez odpowiednią radę wydziału. Pracę dyplomową student wykonuje pod kierunkiem promotora, czyli nauczyciela akademickiego co najmniej ze stopniem doktora habilitowanego. Jednak po zasięgnięciu opinii rady wydziału odpowiedni dziekan może funkcję promotora powierzyć innemu nauczycielowi akademickiemu zatrudnionemu na stanowisku adiunkta, starszego wykładowcy lub osobie spoza uczelni co najmniej ze stopniem naukowym doktora.

Studenci Uniwersytetu Ekonomicznego we Wrocławiu mają możliwość wyboru promotora z ograniczeniami, jakie wynikają z uchwały Senatu i decyzji rady danego wydziału (Uchwała nr R.0000.34.2016 Senatu Uniwersytetu Ekonomicznego we Wrocławiu z dnia 28 kwietnia 2016 r., http://www.ue.wroc.pl/p/dla_pracownikow/uchwaly_senatu_2016/us34_2016.pdf). Studentowi przysługuje prawo do zmiany promotora po pierwszych lub drugich zajęciach seminaryjnych pierwszego semestru seminarium. W tej sprawie wniosek do dziekana nie musi być uzasadniony. Nie jest też potrzebna zgoda dotychczasowego promotora. Wniosek złożony po dwóch pierwszych zajęciach wymaga uzasadnienia. Dziekan w tej sytuacji ma prawo zasięgnąć opinii dotychczasowego promotora (Uchwała nr R.0000.34.2016 Senatu Uniwersytetu Ekonomicznego we Wrocławiu z dnia 28 kwietnia 2016 r., http://www.ue.wroc.pl/ /p/dla_pracownikow/uchwaly_senatu_2016/us34_2016.pdf).

W uchwale Senatu zwraca się uwagę, że temat pracy dyplomowej powinien uwzględniać zainteresowania naukowe studenta i nie może być mu narzucony bez jego akceptacji. Dziekan może również wyrazić zgodę na napisanie pracy dyplomowej w języku obcym, a także zespołowo, pod warunkiem wyraźnego określenia wkładu poszczególnych autorów. Wiąże się to z osobną oceną wkładu każdego autora.

Praca dyplomowa studenta jest oceniana przez promotora i recenzenta. W razie rozbieżności w ocenie pracy co do dopuszczenia do jej obrony na egzaminie dyplomowym może on zasięgnąć opinii drugiego recenzenta.

Należy zaznaczyć, że przed egzaminem dyplomowym praca dyplomowa podlega kontroli ze względu na prawa autorskie w systemie antyplagiatowym, zgodnie z wytycznymi Prawa o szkolnictwie wyższym.

W paragrafie 24 Uchwała Senatu określa warunki i tryb przeprowadzania egzaminu dyplomowego, który ma na celu sprawdzenie wiedzy i umiejętności z zakresu treści programowych odpowiadających kierunkowi studiów. Jednakże jego głównym celem jest sprawdzenie, czy praca dyplomowa została samodzielnie przygotowana przez studenta. Egzamin dyplomowy odbywa się przed komisją powołaną przez dziekana, w skład której wchodzą: promotor, recenzent oraz przewodniczący komisji. Co najmniej jedna osoba musi posiadać stopień doktora habilitowanego lub tytuł naukowy. Przewodniczącym komisji może być dziekan, prodziekan lub osoba wyznaczona spośród samodzielnych pracowników naukowych.

Paragraf 25 Uchwały Senatu określa, że egzamin dyplomowy jest prowadzony w formie ustnej i zgodnie $\mathrm{z}$ postanowieniem danej rady wydziału może polegać na udzielaniu odpowiedzi na pytania weryfikujące efekty kształcenia, pytania losowane albo zadawane 
przez komisję. Istnieje też możliwość prezentacji istotnych osiągnieć z pracy dyplomowej przez studenta. Złożenie egzaminu dyplomowego z wynikiem pozytywnym jest równorzędne z ukończeniem studiów przez studenta.

Celem niniejszego artykułu jest próba określenia oczekiwań studentów rachunkowości Uniwersytetu Ekonomicznego we Wrocławiu co do formy wyboru promotora, przebiegu seminariów, a także zasad kontaktu na linii promotor-seminarzysta. W artykule zastosowano metodę dedukcji, indukcji oraz wnioskowania przez analogię na podstawie otrzymanych ankiet.

\section{MATERIA I METODY}

$\mathrm{Na}$ potrzeby wnioskowania badawczego oraz przedstawienia wniosków zastosowano w artykule metodę indukcji, wykorzystując przeprowadzone badania ankietowe. Opracowanie artykułu zostało poprzedzone badaniami empirycznymi, których podstawą była ankieta badawcza skierowana do studentów III roku studiów stacjonarnych I stopnia Wydziału Zarządzania, Informatyki i Finansów na Uniwersytecie Ekonomicznym we Wrocławiu.

Wykorzystany do celów badawczych kwestionariusz ankiet zawierał 17 pytań szczegółowych (zob. tab. 1).

Badania ankietowe nt. seminariów dyplomowych zostały przeprowadzone wśród studentów urodzonych w latach 1995, 1996, zaliczanych do generacji Z. Badaniem objęto 93 studentów z 4 grup, w tym: 2 z grupy ze specjalności rachunkowości i auditing oraz 2 z grupy ze specjalności rachunkowość i podatki na studiach licencjackich Wydziału Zarządzania, Informatyki i Finansów Uniwersytetu Ekonomicznego we Wrocławiu.

W celu zachęcenia studentów do odpowiedzi na zawarte w ankiecie pytania poproszono ich o wybór przy każdym pytaniu tylko jednej odpowiedzi; otrzymano 84 wypełnione ankiety (90\%).

\section{WYNIKI I DYSKUSJA}

$\mathrm{Na}$ podstawie otrzymanych ankiet przygotowano tabelaryczne zestawienie odpowiedzi. W tabeli 1 przedstawiono zadane pytania, możliwe odpowiedzi oraz procent ankietowych, którzy zaznaczyli daną odpowiedź.

Tabela 1. Ankieta i udzielone odpowiedzi dot. wyboru promotora

\begin{tabular}{|c|c|c|c|}
\hline $\mathrm{Nr}$ & Pytanie & Odpowiedź & [\%] \\
\hline \multirow{2}{*}{1} & \multirow{2}{*}{$\begin{array}{l}\text { Czy wybór promotora nastąpił zgodnie } \\
\text { z twoim założeniem? }\end{array}$} & tak & 62 \\
\hline & & nie & 38 \\
\hline \multirow{2}{*}{2} & \multirow{2}{*}{$\begin{array}{l}\text { Czy miałeś(-aś) kilku tzw. rezerwowych } \\
\text { promotorów do wyboru? }\end{array}$} & tak & 90 \\
\hline & & nie & 10 \\
\hline \multirow{2}{*}{3} & \multirow{2}{*}{$\begin{array}{l}\text { Jak oceniasz obecny system zapisów do } \\
\text { promotorów? }\end{array}$} & dobrze & 64 \\
\hline & & źle & 36 \\
\hline \multirow{5}{*}{4} & \multirow{5}{*}{$\begin{array}{l}\text { Jaka forma, wg Ciebie, odpowiadałaby } \\
\text { najlepiej zapisom do promotorów? }\end{array}$} & zapisy wg średniej dla wszystkich studentów & 48 \\
\hline & & wybór przez promotora seminarzystów & 19 \\
\hline & & losowość & 1 \\
\hline & & kto pierwszy, ten lepszy & 4 \\
\hline & & $\begin{array}{l}\text { zapisy podzielone na dwie grupy - studenci ze } \\
\text { stypendium i bez stypendium }\end{array}$ & 28 \\
\hline
\end{tabular}


Tabela 1. Ankieta i udzielone odpowiedzi dot. wyboru promotora (cd.)

\begin{tabular}{|c|c|c|c|}
\hline $\mathrm{Nr}$ & Pytanie & Odpowiedź & {$[\%]$} \\
\hline \multirow{4}{*}{5} & \multirow{4}{*}{$\begin{array}{l}\text { Co uważasz za słabość obecnej formy } \\
\text { zapisów na seminaria? }\end{array}$} & $\begin{array}{c}\text { obecną formę zapisów (osoby ze stypendium } \\
\text { jako pierwsze w pierwszym dniu, pozostałe } \\
\text { osoby, kto szybszy, w drugim dniu) }\end{array}$ & 20 \\
\hline & & $\begin{array}{c}\text { jakość połączenia internetowego w momencie } \\
\text { zapisów }\end{array}$ & 45 \\
\hline & & małą liczbę promotorów & 1 \\
\hline & & $\begin{array}{l}\text { brak możliwości poznania wszystkich } \\
\text { promotorów osobiście przed zapisami }\end{array}$ & 34 \\
\hline \multirow{2}{*}{6} & \multirow{2}{*}{$\begin{array}{l}\text { Czy promotorzy powinni zaproponować tzw. } \\
\text { drzwi otwarte przed zapisaniem się do nich } \\
\text { na seminaria? }\end{array}$} & tak & 71 \\
\hline & & nie & 29 \\
\hline \multirow{2}{*}{7} & \multirow{2}{*}{$\begin{array}{l}\text { Czy promotorzy powinni mieć ograniczoną } \\
\text { liczbę osób w grupie seminaryjnej? }\end{array}$} & tak & 99 \\
\hline & & nie & 1 \\
\hline \multirow{4}{*}{8} & \multirow{4}{*}{$\begin{array}{l}\text { Jaka powinna być optymalna wielkość grupy } \\
\text { seminaryjnej? }\end{array}$} & 1-10 osób & 70 \\
\hline & & 11-20 osób & 20 \\
\hline & & 21-30 osób & 7 \\
\hline & & bez ograniczeń & 3 \\
\hline \multirow{5}{*}{9} & \multirow{5}{*}{$\begin{array}{l}\text { Czym się kierowałeś(-aś), wybierając } \\
\text { promotora? }\end{array}$} & wcześniejszym poznaniem na zajęciach & 48 \\
\hline & & tytułem naukowym & 1 \\
\hline & & aparycją & 15 \\
\hline & & $\begin{array}{l}\text { informacjami studentów na forach } \\
\text { internetowych }\end{array}$ & 31 \\
\hline & & przygotowaną przez promotora ofertą & 5 \\
\hline \multirow{4}{*}{10} & \multirow{4}{*}{$\begin{array}{l}\text { Skąd czerpałeś(-aś) informacje o promotorze } \\
\text { i prowadzonych przez niego seminariach? }\end{array}$} & oferta seminaryjna & 7 \\
\hline & & grupy studenckie na facebooku & 64 \\
\hline & & rozmowy ze studentami starszych roczników & 25 \\
\hline & & pozostałe formy w internecie & 4 \\
\hline \multirow{2}{*}{11} & \multirow{2}{*}{$\begin{array}{l}\text { Czy przed zapisem przeglądałeś(-aś) ofertę } \\
\text { seminaryjną danego promotora? }\end{array}$} & tak & 79 \\
\hline & & nie & 21 \\
\hline \multirow{2}{*}{12} & \multirow{2}{*}{$\begin{array}{l}\text { Czy jesteś zadowolony(-na) ze swojego } \\
\text { promotora? }\end{array}$} & tak & 73 \\
\hline & & nie & 27 \\
\hline \multirow{2}{*}{13} & \multirow{2}{*}{ Czy myślisz o zmianie promotora? } & tak & 44 \\
\hline & & nie & 56 \\
\hline \multirow{2}{*}{14} & \multirow{2}{*}{ Czy zmieniłeś(-aś) promotora? } & tak & 5 \\
\hline & & nie & 95 \\
\hline \multirow{5}{*}{15} & \multirow{5}{*}{$\begin{array}{l}\text { Co, wg Ciebie, wpływa na zmianę } \\
\text { promotora? }\end{array}$} & aparycja & 10 \\
\hline & & sposób zachowania & 14 \\
\hline & & odnoszenie się do studentów & 25 \\
\hline & & brak przygotowania merytorycznego & 5 \\
\hline & & utrudniony kontakt & 46 \\
\hline \multirow{2}{*}{16} & \multirow{2}{*}{$\begin{array}{l}\text { Czy w sprawie swojej pracy licencjackiej } \\
\text { kontaktujesz się (poza swoim promotorem) } \\
\text { z innym pracownikiem naukowym? }\end{array}$} & tak & 44 \\
\hline & & nie & 56 \\
\hline \multirow{8}{*}{17} & & seminarium tradycyjne grupowe & 18 \\
\hline & & seminarium indywidualne & 35 \\
\hline & & facebook & 24 \\
\hline & Jaki kontakt z promotorem preferujesz & telefon & 8 \\
\hline & w związku z pisaniem pracy licencjackiej? & mail & 10 \\
\hline & & snapchat & 1 \\
\hline & & whatsapp & 2 \\
\hline & & inny komunikator & 2 \\
\hline
\end{tabular}


Pierwsze pytania ankiety dotyczyły wyboru promotora. $62 \%$ ankietowanych zapisało się do promotora, u którego planowało pisać pracę, przy czym aż 90\% stwierdziło występowanie tzw. opcji rezerwowej (ryc. 1, 2) - polegała ona na wytypowaniu kilku promotorów i próbie zapisywania się do nich kolejno według przygotowanej listy.

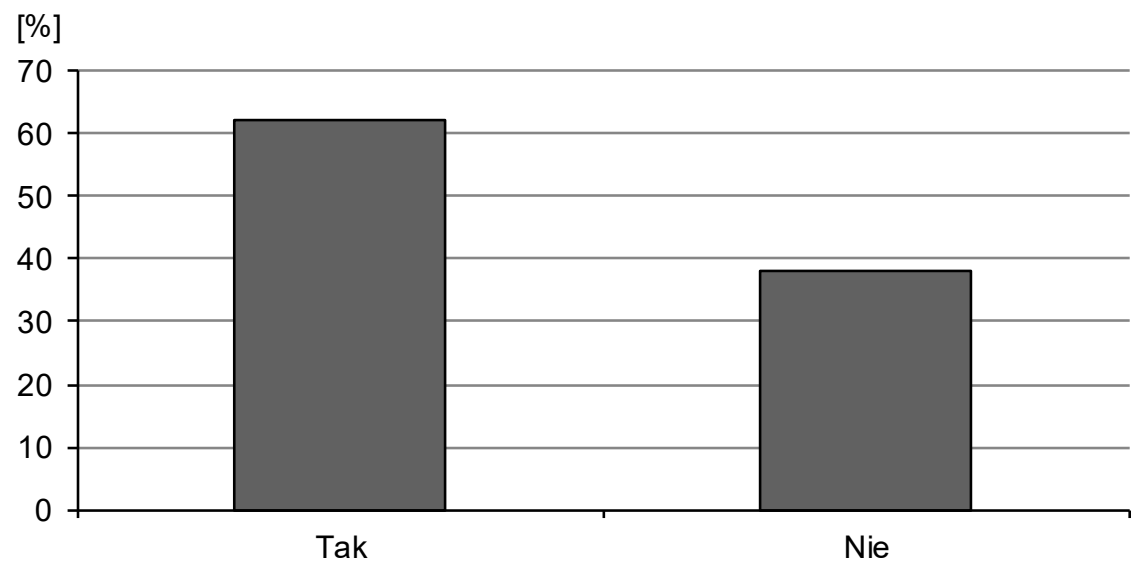

Ryc. 1. Wybór promotora zgodny z własnymi założeniami

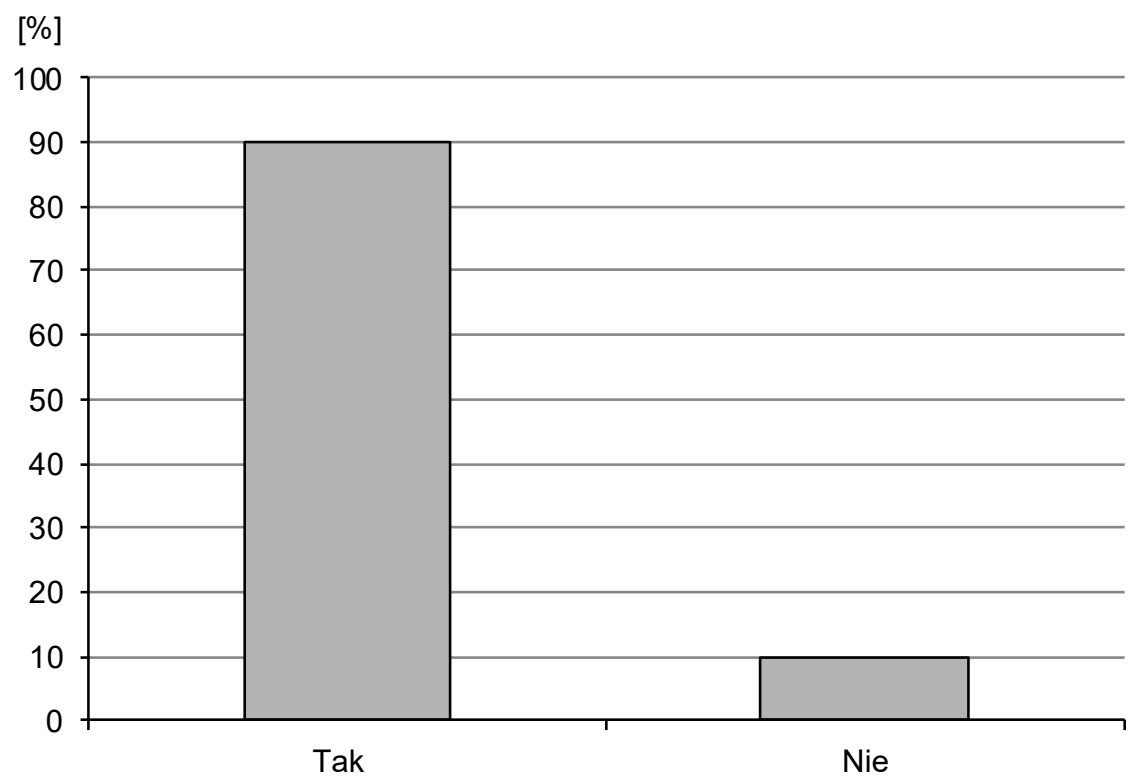

Ryc. 2. Posiadanie tzw. listy rezerwowej promotorów

Kolejne trzy pytania były ukierunkowane na ocenę obecnej formy zapisów. Na Wydziale Zarządzania, Informatyki i Finansów zapisy na seminaria do danego promotora odbywają się drogą internetową. W pierwszym dniu zapisy są otwarte dla osób otrzymujących stypendium naukowe. W drugim dniu zapisują się pozostali studenci. Najczęściej studenci „odświeżają” stronę z zapisami na kilka minut przed uruchomieniem zapisów, co powoduje przeciążenie serwerów. Szacuje się, że zapisy w drugim dniu dotyczą ok. 90\% studentów, z czego prawie wszyscy chcą się zapisać w momencie uruchomienia systemu. W skutek tego taka forma zapisów przybiera postać prostego ataku DDoS, który jest odmianą ataku DDoS, polegającą na zaatakowaniu „ofiary internetowej” z wielu miejsc jednocześnie. 
Wśród ankietowanych aż 64\% stwierdziło, że obecny system zapisów jest zły (ryc. 3). $48 \%$ studentów zasugerowało, że zapisy powinny być uzależnione od średniej wszystkich studentów. W rozmowach osobistych dopuszczali podział na grupy według średniej. 28\% optuje za utrzymaniem obecnego systemu zapisów. Za największe mankamenty obecnej formy zapisów uznano słabą jakość połączenia internetowego (45\% badanych) oraz brak możliwości osobistego poznania wszystkich promotorów (34\%). Omówione wyniki są przedstawione na ryc. 4 i 5.

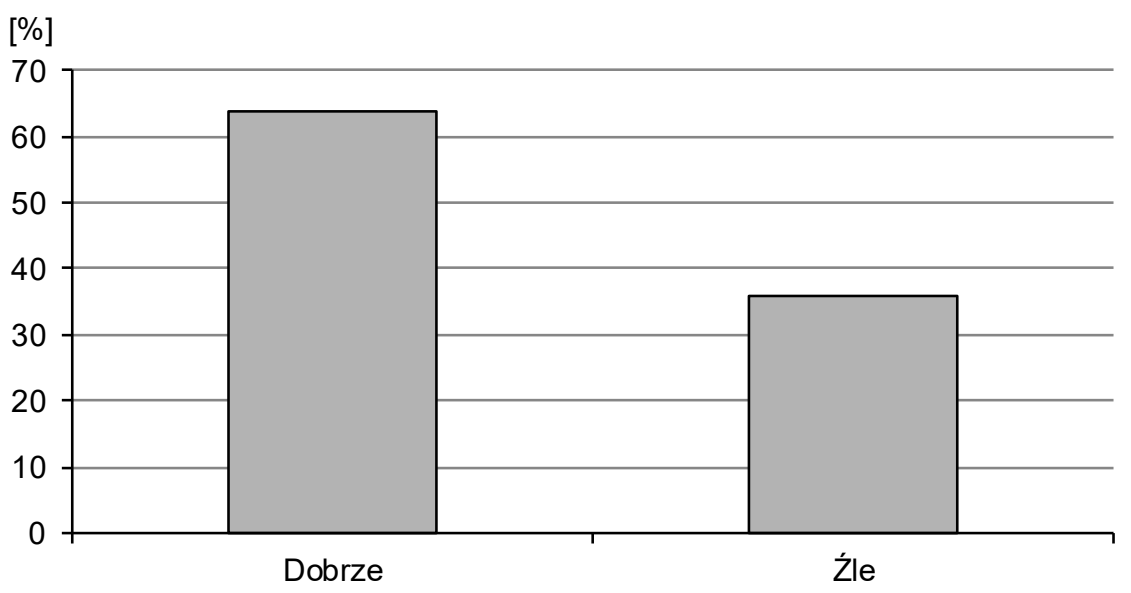

Ryc. 3. Ocena obecnego systemu zapisów

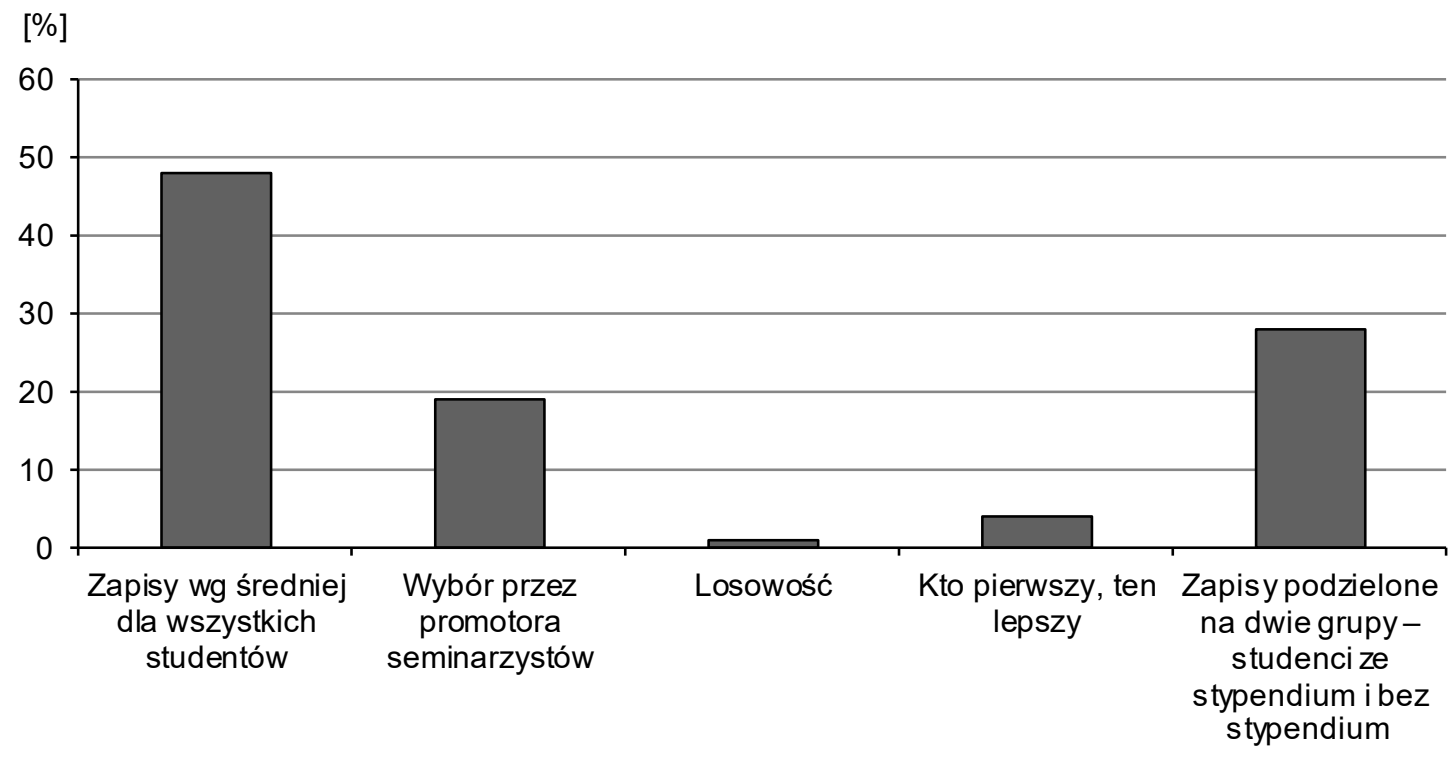

Ryc. 4. Najlepsza forma zapisów na seminaria 


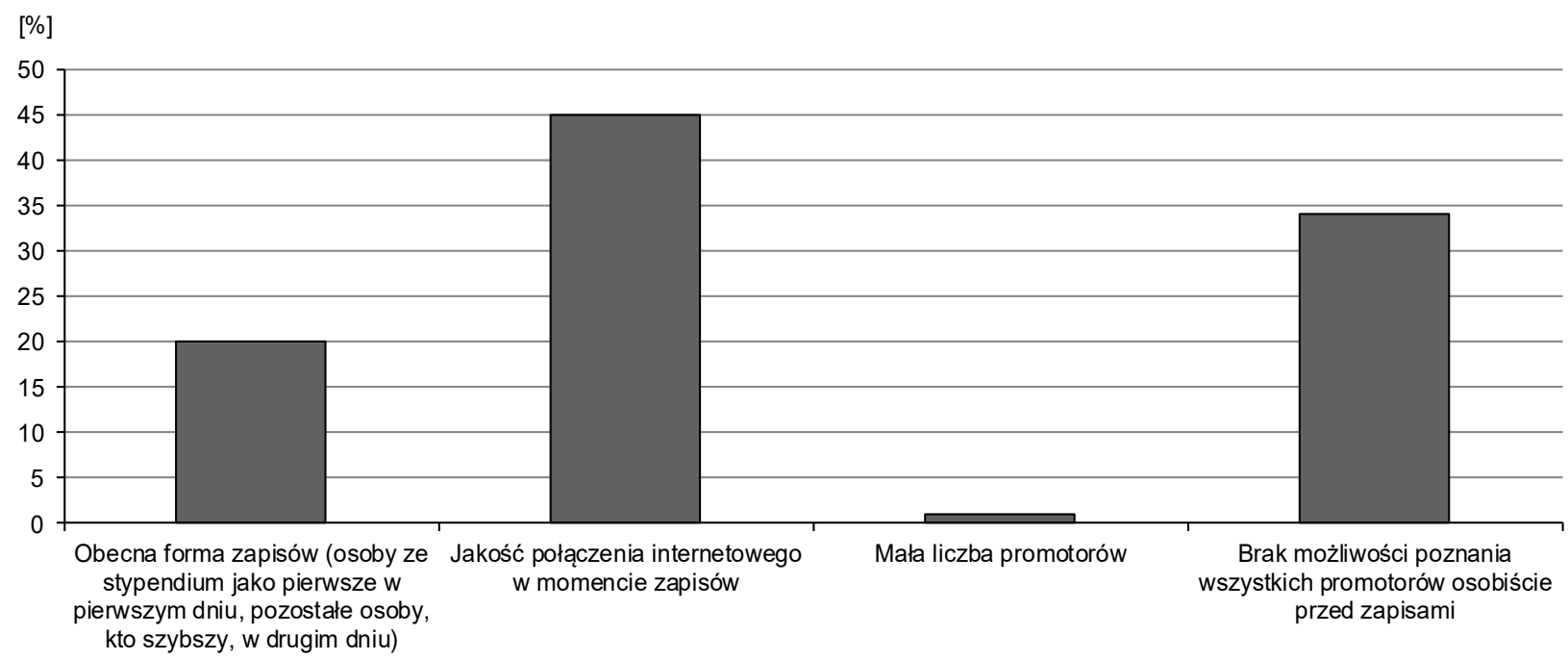

Rys. 5. Minusy obecnej formy zapisów

Pytania 6-11 dotyczyły formy prowadzenia seminarium, liczebności grupy seminaryjnej, przesłanek wyboru promotora. $71 \%$ ankietowanych opowiedziało się za tzw. drzwiami otwartymi promotorów. Miałyby one na celu poznanie promotorów, możliwość osobistego kontaktu z nimi. 99\% badanych zadeklarowało, że grupy seminaryjne powinny być ograniczone, z czego aż 70\% studentów uważa, że grupa powinna liczyć do 10 osób. Pytanie 9 oraz pytanie 10 dotyczyło tego, czym kierują się studenci, wybierając promotora oraz skąd czerpią wiedzę na jego temat. 48\% studentów kierowało się wcześniejszym poznaniem promotora na zajęciach, a 31\% - informacjami od studentów starszych roczników. Ciekawe jest to, że aż 15\% wybrało promotora ze względu na aparycję, schludność, atrakcyjność fizyczną, kindersztubę. Mimo że 79\% ankietowanych przeglądało ofertę seminaryjną danego promotora umieszczoną w internecie, tylko $5 \%$ podjęło na jej podstawie decyzję o zapisach. Jeżeli chodzi o źródło informacji o promotorze, większość, bo prawie 2/3 ankietowych (64\%), skorzystała z forów internetowych na facebooku, a 1/4 (25\%) - z rozmów ze studentami starszych roczników. Wyniki są zaprezentowane na ryc. 6-11.

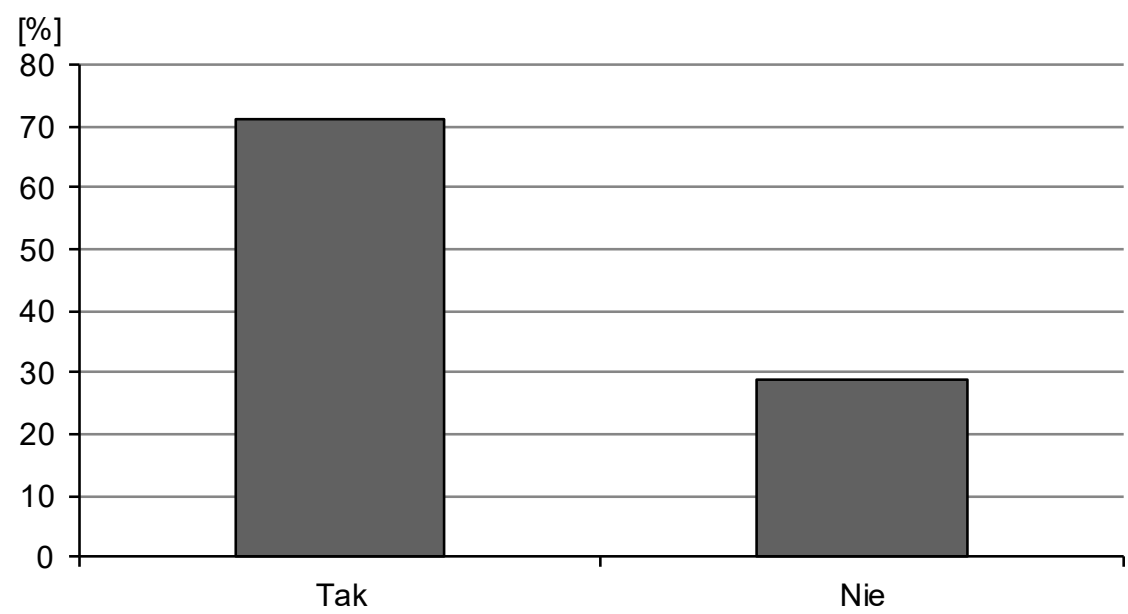

Rys. 6. „Drzwi otwarte” promotorów 


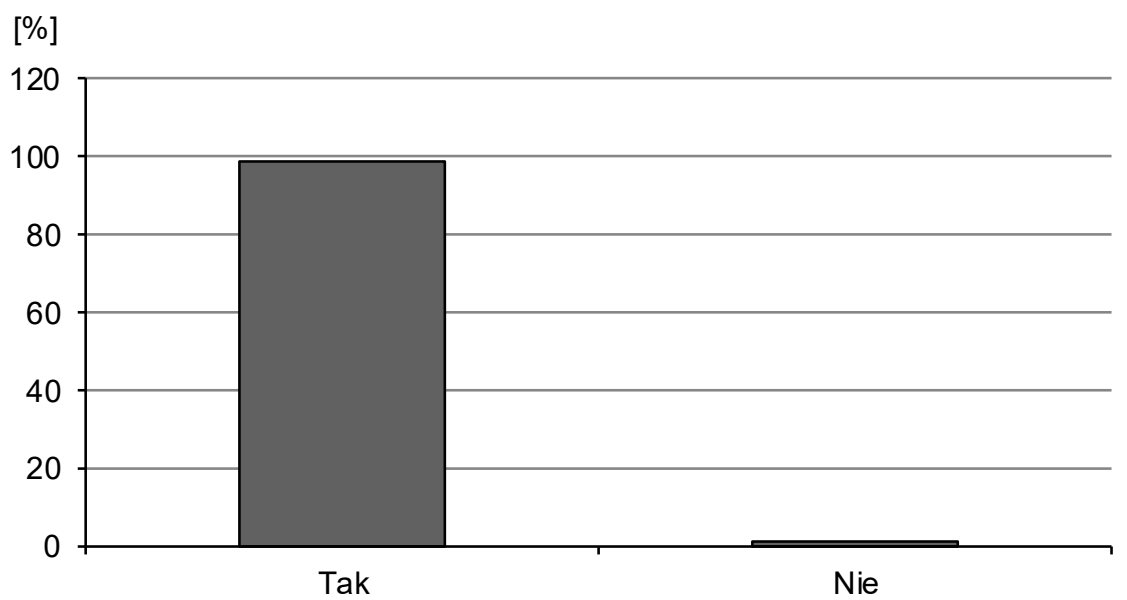

Ryc. 7. Ograniczona liczba osób w grupie seminaryjnej

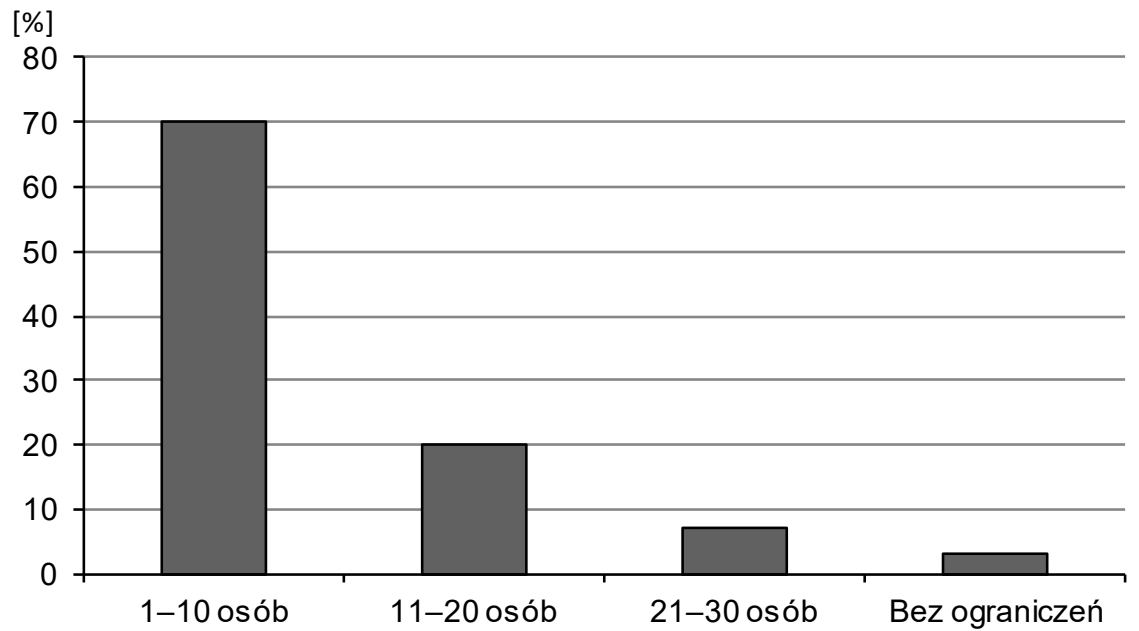

Ryc. 8. Preferowana liczebność grupy seminaryjnej

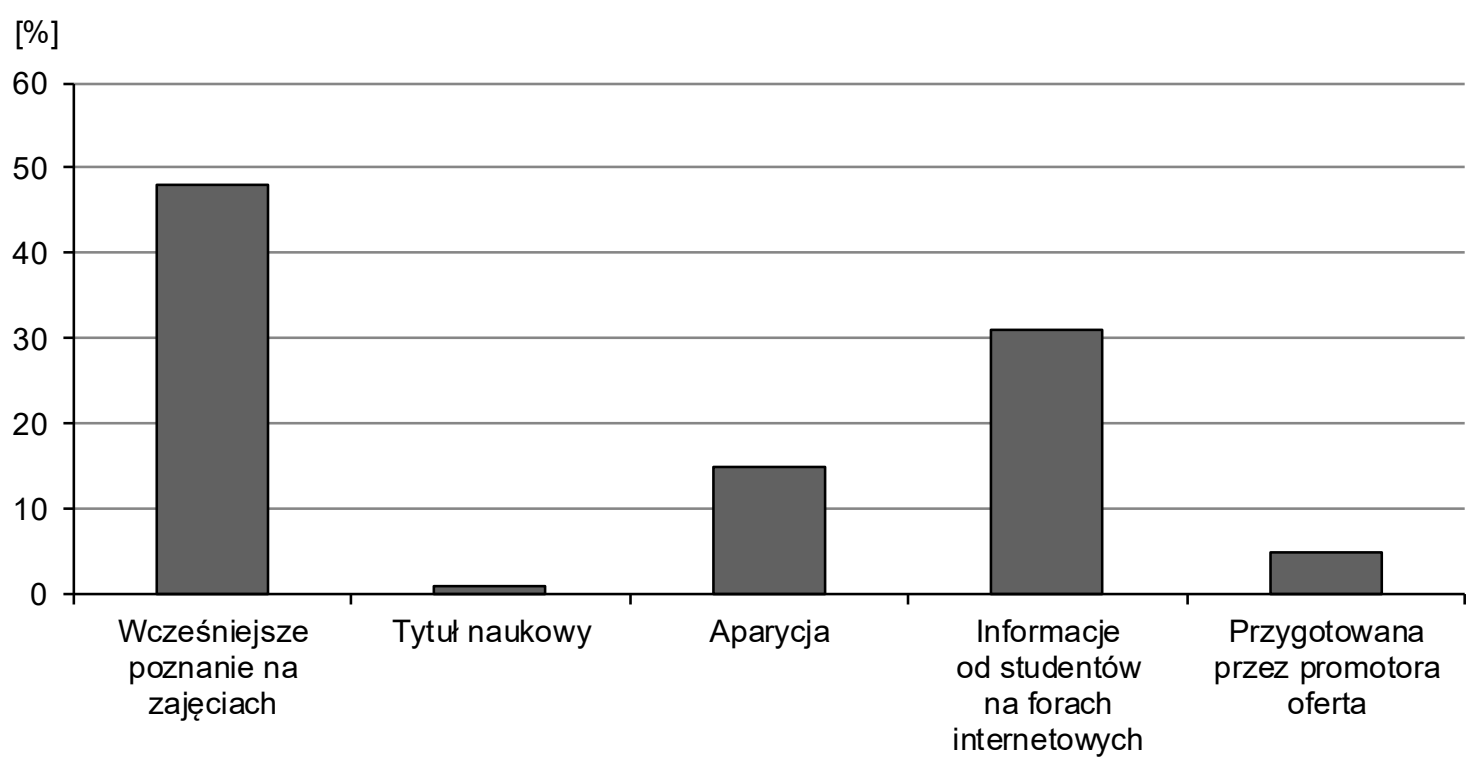

Ryc. 9. Przesłanki wyboru promotora 


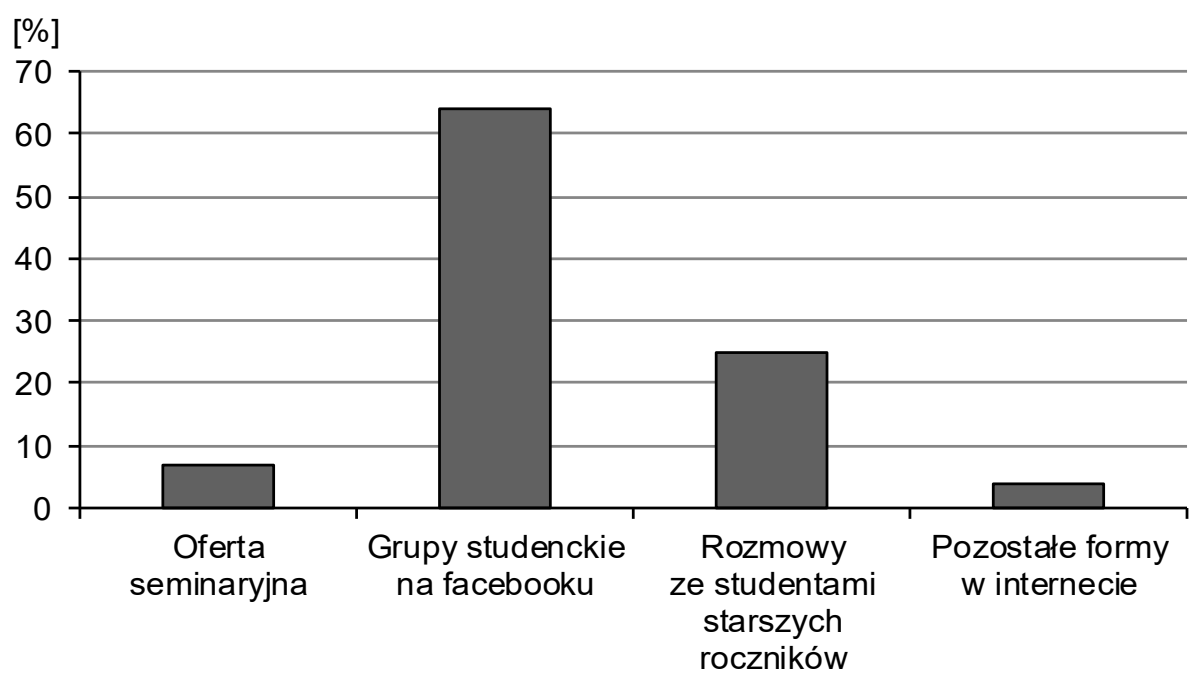

Ryc. 10. Źródło informacji o promotorze

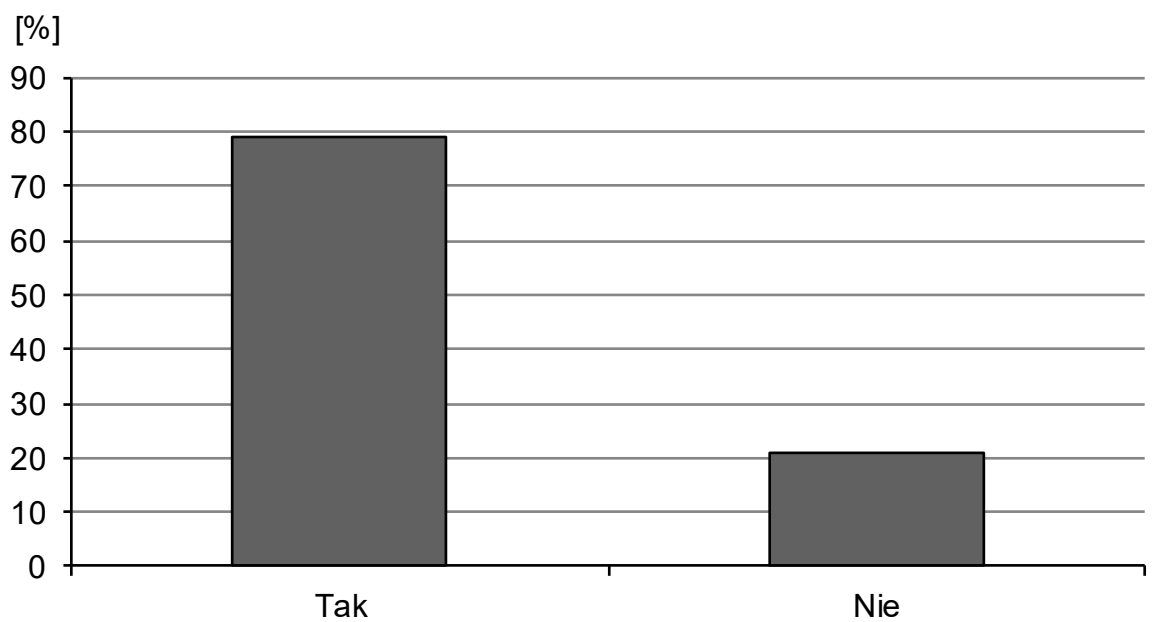

Ryc. 11. Przeglądanie oferty seminaryjnej

$\mathrm{Na}$ podstawie odpowiedzi na pytania 12-15 można ocenić zadowolenie studentów z promotorów i ewentualne zmiany osób prowadzących seminaria. $73 \%$ studentów jest zadowolonych ze swojego promotora, ale mimo to aż $44 \%$ rozważa potrzebę zmiany promotora. Do tej pory na to zdobyło się zaledwie $5 \%$. Studenci określili również przyczyny ewentualnej zmiany promotora. $46 \%$ zaznaczyło, że powodem jest utrudniony kontakt z prowadzącym seminaria, a 25\% - że lekceważenie studentów (ryc. 12-15).

Ostatnie dwa pytania ankiety dotyczyły form kontaktu studentów z promotorem oraz konsultacji w sprawie pracy z pracownikiem naukowym, który nie jest promotorem. Aż $44 \%$ studentów kontaktuje się i konsultuje swoją pracę z innym pracownikiem naukowym uczelni. Z rozmów przeprowadzonych poza ankietą wynika, że są to głównie osoby prowadzące zajęcia z innych przedmiotów powiązanych tematycznie z pracą oraz że dotyczą seminarzystów zapisanych do pracowników naukowych ze stopniem profesora zwyczajnego. W tej sytuacji osobami, z którymi kontaktują się studenci, są głównie adiunkci. Stają się zatem oni nieformalnymi promotorami pomocniczymi. Jednocześnie należy zwrócić uwagę, że 35\% studentów preferuje indywidualne spotkania dotyczące pisanej przez nich pracy licencjackiej, 
a $24 \%$ chciałaby mieć kontakt z promotorem przez komunikator internetowy w postaci facebooka; bardzo mało popularny jest kontakt mailowy. Jedynie 10\% ankietowanych preferuje tę formę kontaktu. Odpowiedzi otrzymane na te pytaniach są zaprezentowane na ryc. 16 i 17.

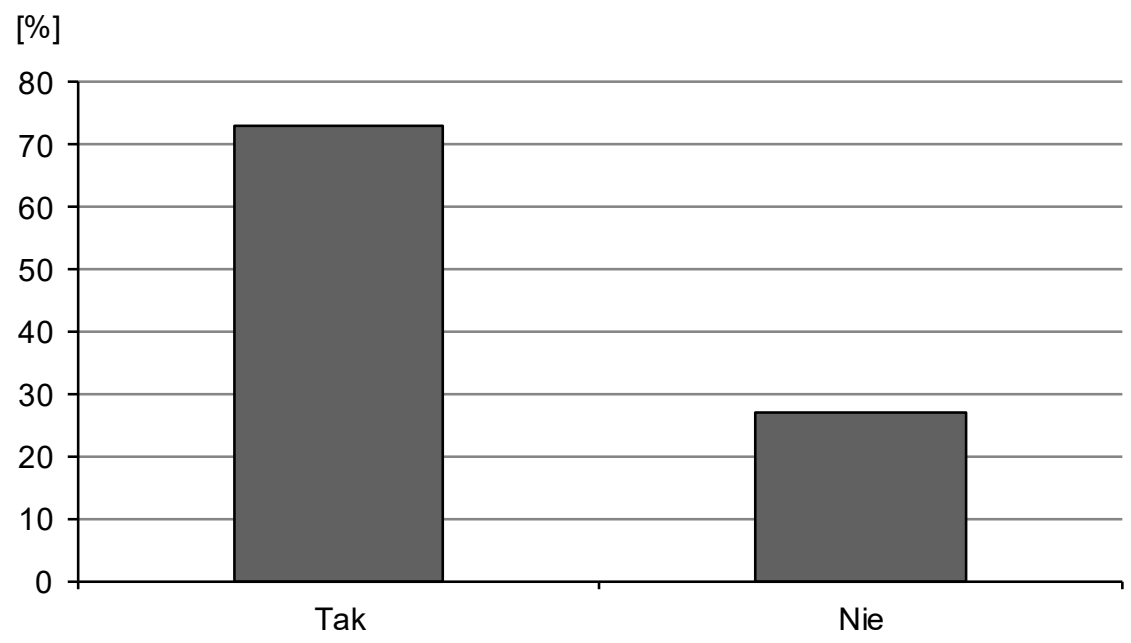

Ryc. 12. Zadowolenie z obecnego promotora

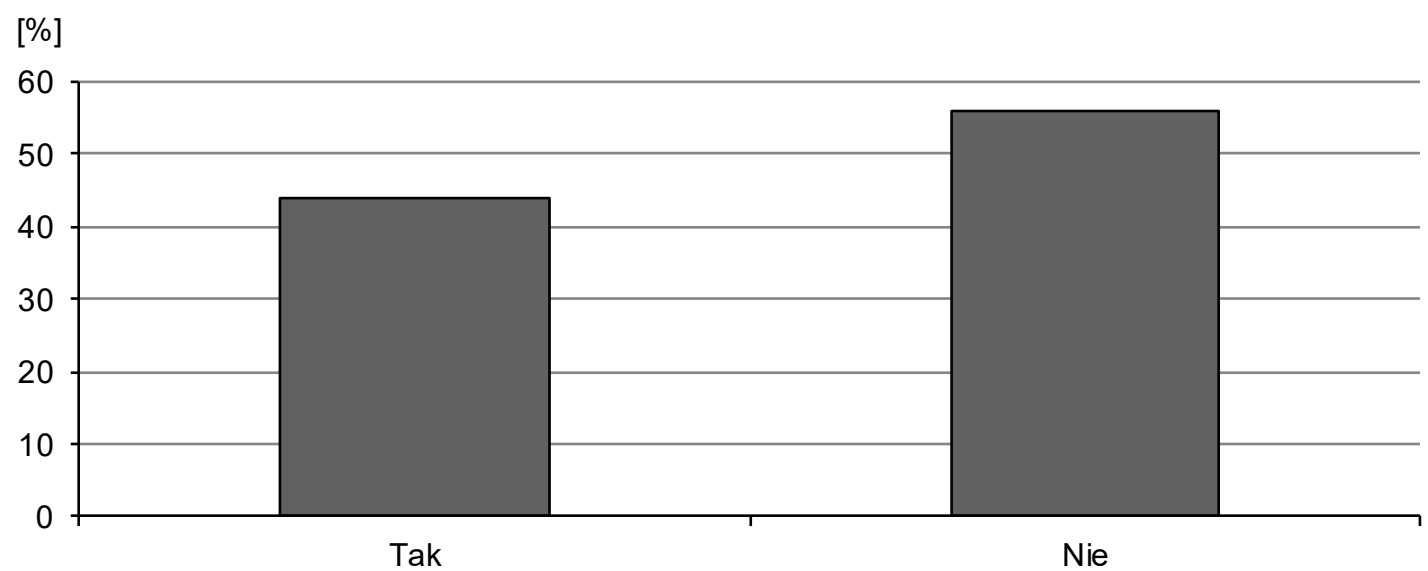

Ryc. 13. Potencjalna zmiana promotora

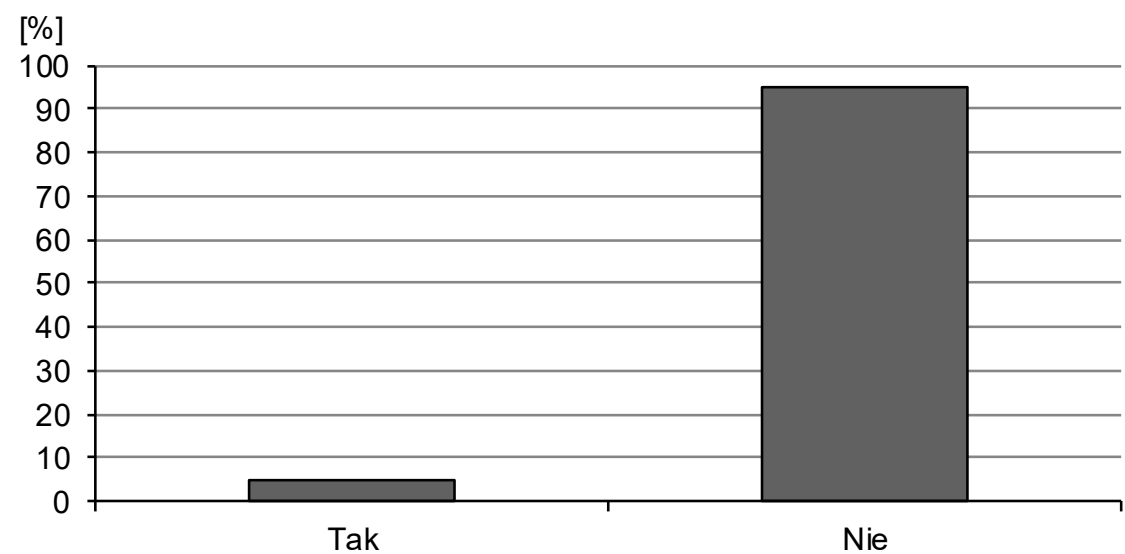

Ryc. 14. Dokonana zmiana promotora 
[\%]

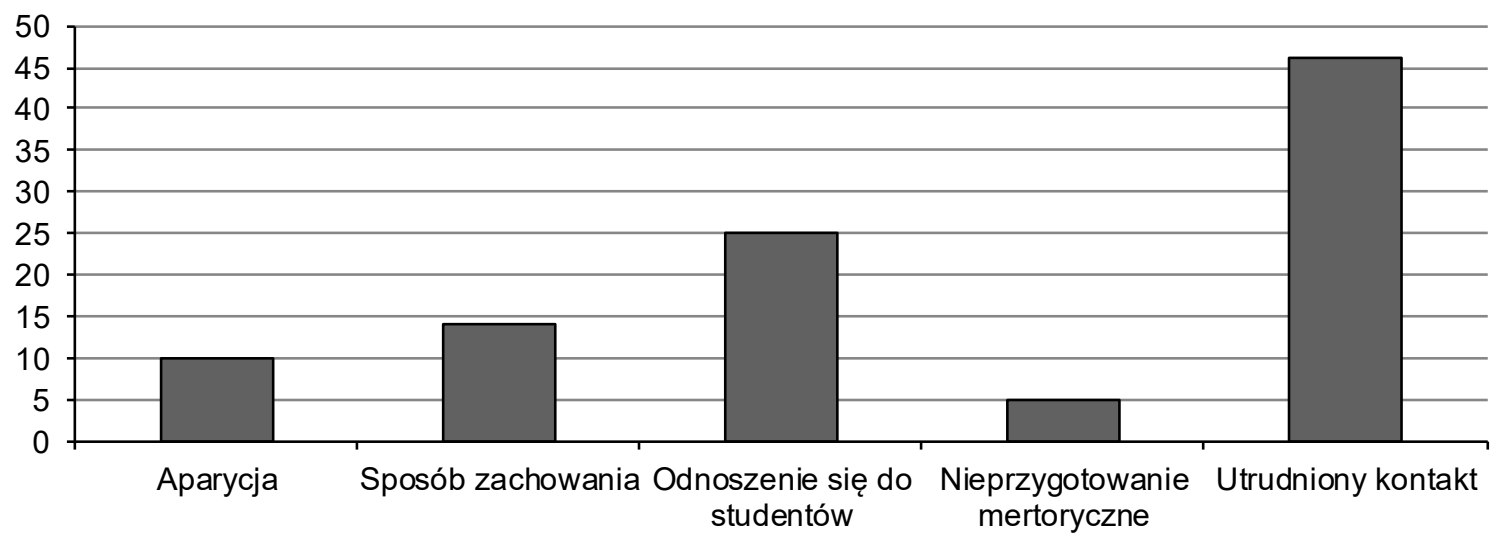

Ryc. 15. Czynniki wpływające na zmianę promotora

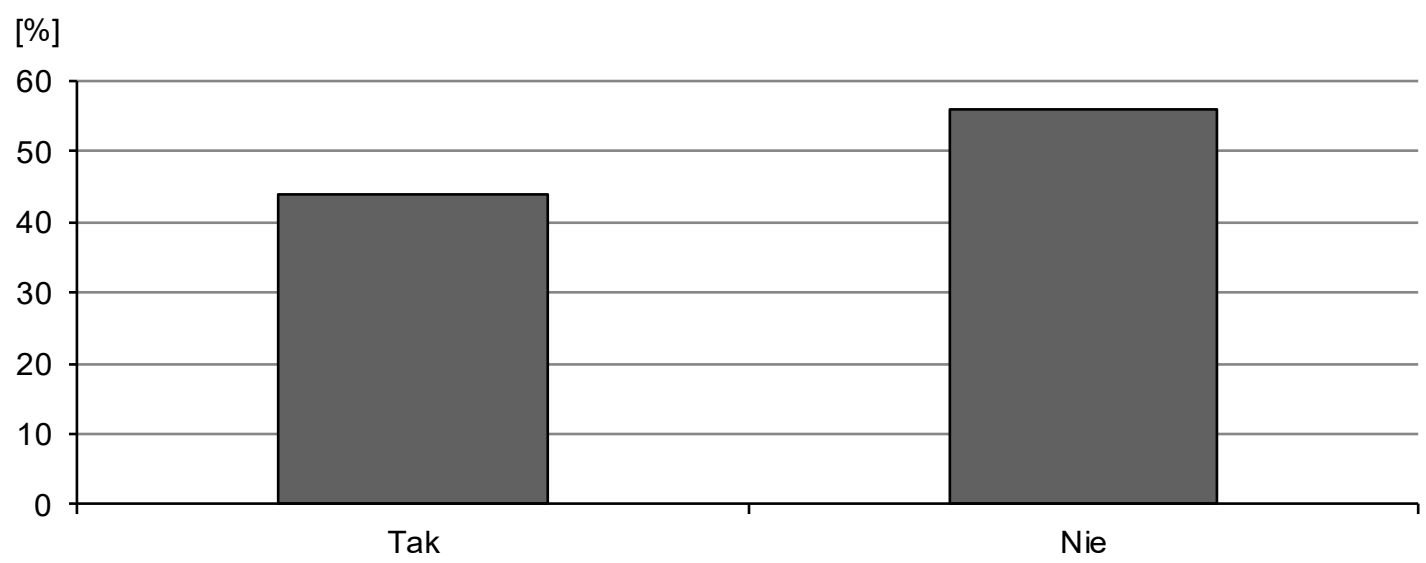

Ryc. 16. Kontakt $z$ innymi pracownikami naukowymi podczas pisania pracy licencjackiej

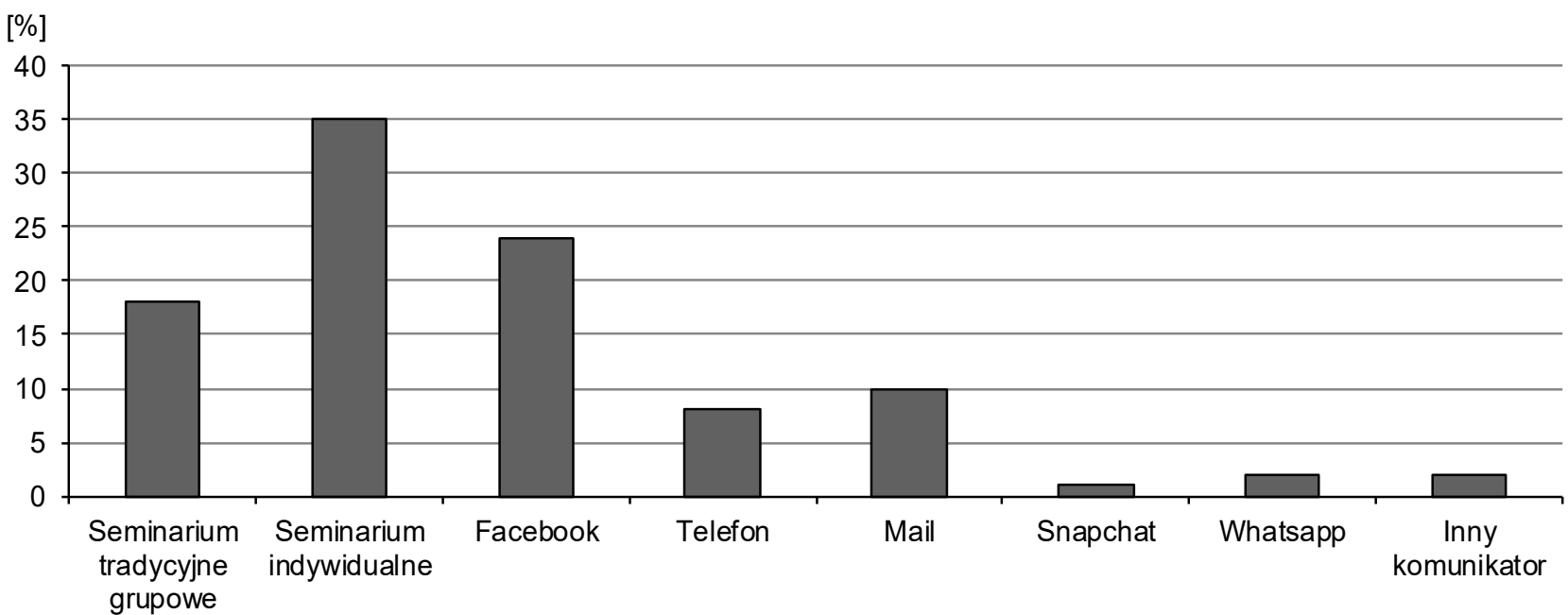

Ryc. 17. Preferowana forma kontaktu

\section{PODSUMOWANIE}

Na podstawie wyników badań ankietowych można ocenić pogląd studentów studiów stacjonarnych I stopnia rachunkowości Uniwersytetu Ekonomicznego we Wrocławiu na Wydziale Zarządzania, Informatyki i Finansów na formę zapisów i wyboru promotorów. Otrzymane 
wyniki są zbieżne z obecną wiedzą zarówno pracowników naukowych, jak i administracyjnych w dziekanacie.

Na podstawie otrzymanych odpowiedzi można sformułować następujące wnioski:

- studenci rachunkowości Uniwersytetu Ekonomicznego we Wrocławiu z generacji Z oczekują szybkiego i bezpośredniego kontaktu z promotorem;

- większość studentów preferuje indywidualne spotkania seminaryjne; grupa seminaryjna powinna liczyć nie więcej niż 10 osób, co umożliwi promotorowi skupienie się na pracy danego studenta;

- informacje o prowadzących seminaria studenci uzyskują z ogólnodostępnych forów internetowych i kontaktów ze starszymi rocznikami;

- studenci preferują osoby bez tytułu profesora jako pomocniczych promotorów przy pisaniu pracy lub rozwiązywaniu problemów z nią związanych;

- obecna forma zapisów na Wydziale ZIF UE we Wrocławiu jest oceniana krytycznie;

- należy wprowadzić „drzwi otwarte” dla przyszłych seminarzystów, w szczególności dla osób, które nie miały wcześniej kontaktu z potencjalnym promotorem;

- należy wykorzystać Social Media do kontaktów ze studentami.

Podsumowując, można stwierdzić, że oczekiwania większości studentów rachunkowości z pokolenia Z, dotyczące wyboru promotora, form kontaktu z nim i systemu zapisu, mają iść $z$ duchem czasu i postępem technologicznym. Koniecznością wydaje się kontaktowanie się promotora ze swoimi seminarzystami przez Facebook, a także poświęcenie przez niego większej ilości czasu każdemu seminarzyście. Studenci oczekują, że nie będą traktowani jako „masa”. Mają oni świadomość, że są unikatowi i jedyni, dlatego tak chcą być odbierani i traktowani przez pracowników naukowych.

\section{PIŚMIENNICTWO}

Pawłowska M. Generacja Z. Młodzi, otwarci, wychowani w dobrobycie, żyjący w świecie wirtualnym, skazani na kryzys, http://natemat.pl/55617,generacja-z-mlodzi-otwarci-wychowani-w-dobrobyciezyjacy-w-swiecie-wirtualnym-skazani-na-kryzys, dostęp: 30.10.2016.

Uchwała nr R.0000.34.2016 Senatu Uniwersytetu Ekonomicznego we Wrocławiu z dnia 28 kwietnia 2016 r., http://www.ue.wroc.pl/p/dla_pracownikow/uchwaly_senatu_2016/us34_2016.pdf, dostęp: 31.10.2016.

Ustawa z dnia 27 lipca 2005 r. Prawo o szkolnictwie wyższym. DzU z 2005 r., nr 164, poz. 1365, z późn. zm. 